\title{
Tensão na ciência política brasileira: a produção dos doutores e a percepção dos editores
}

\author{
Nelson Rosário de Souza \\ Professor Doutor da Universidade Federal do Paraná, Curitiba, Paraná, Brasil \\ nrdesouza@ufpr.br
}

Fabiane Helene Valmore Mestre pela Universidade Federal do Paraná, Curitiba, Paraná, Brasil fh.valmore@bol.com.br

Resumo A Ciência Política no Brasil experimenta a tensão entre as abordagens institucionalista e societal. Para alguns, é positivo o papel preponderante do institucionalismo; outros entendem que esta hegemonia cria desigualdade na área e prejudica a reflexão sobre a democracia. Portanto, objetivamos descrever a produção recente (2005-2014) em importantes periódicos do campo da Ciência Política comparando institucionalismo e societalismo com atenção especial aos artigos sobre democracia e desigualdade. Observamos, quantitativamente e qualitativamente, a produção dos doutores em Ciência Política em sete importantes periódicos científicos. A percepção dos editores dos periódicos sobre esse processo completa o corpus. Concluímos que a hegemonia institucionalista se confirma na produção dos doutores, mas não sem gerar insatisfações.

Palavras-chave: Ciência Política. Doutores. Editores. Periódicos. Artigos.

\section{Introdução}

A reflexão sobre a história da Ciência Política no Brasil tem se intensificado.Busca-se mapear temas, teorias, métodos e a produção paralelamente ao seu processo de autonomização ${ }^{1}$. As evidências apontam para o dilema vivido pela Ciência Política brasileira na construção

1 Ver Marques; Machado (2014); Oliveira; Nicolau (2014); Leite (2015); Neiva (2015); Barbosa; Godoy (2015); e Amorim Neto; Santos (2015). 
de sua identidade. De um lado, a experiência recente de progresso na delimitação de suas fronteiras, na especialização de seus profissionais e na constituição de seus objetos e método, isso tudo sob a hegemonia da abordagem institucionalista2. De outro, o risco de excessivo fechamento teórico e da desigualdade na distribuição de recursos dentro do campo devido à rígida hierarquia.

Evidências dessa tensão estão na literatura da área, para autores como André Marenco (2014), Fernando Limongi, Maria Hermínia Tavares de Almeida e Andrea Freitas (Limongi et al., 2015) a hegemonia institucionalista deve ser saudada, pois tem sido fundamental para consolidação da Ciência Política no Brasil, sem prejuízo para o pluralismo. Do outro lado da controvérsia, pensadores como José Álvaro Moisés (1995), Daniela Mussi (2014), Renato Perissinotto (2004) e Gabriel Vitullo (2016) criticam a excessiva valorização politológica, que oferece o risco de transformar uma escolha teórico-metodológica em critério de cientificidade (Leite, 2015), colocando à sombra aspectos societais ${ }^{3}$ fundamentais para compreensão da política. Posturas conciliatórias aparecem em autores como Renato Perissinotto (2004), Thamy Pogrebinschi (2010) e Fábio Wanderley Reis (2015).

A tensão apontada acima e sua manifestação nos periódicos não esgotam as características do campo em tela, todavia constituem parte relevante dele, pois contribuem para a compreensão da hierarquia de assuntos na área. A distribuição dos artigos nos periódicos não atesta por si só a referida tensão no campo. Mas os periódicos se oferecem como fonte interessante para medir aspectos dessa tensão tratada pela literatura. Sendo assim, o objetivo é mapear a tensão entre institucionalismo e societalismo, em um exercício introdutório e didático, analisando duas séries de dados. Primeiramente, a produção publicada exclusivamente por doutores em Ciência Política, entre 2005 e 2014, em sete periódicos nacionais: Brazilian Political Science Review (BPSR), Dados, Lua Nova, Revista Brasileira de Ciências Sociais (RBCS), Revista de Sociologia e Política (RSP), Opinião Pública (OP) e Revista Brasileira de Ciência Política (RBCP).

Optamos pelos doutores para fotografar a produção de 'especialistas' do campo. Trata-se de um grupo pouco estudado quanto à preferência de assuntos. $\mathrm{O}$ recorte temporal possibilita verificar a disputa em tela no cenário recente, de forte crescimento do número de doutores no Brasil, taxa de 52,9\% (CGEE, 2016), e também de expansão e consolidação da pós-graduação em Ciência Política. No período de 2004 a 2012, houve forte crescimento no número de alunos matriculados em Programas de Pós-Graduação

2 Abordagem que enfatiza as instituições formais do Estado e do governo, tais como partidos, sistemas partidários, casas legislativas, Poder Executivo, sistema eleitoral etc., dando especial atenção às suas regras e seus atores internos, com o objetivo de explicar os processos decisórios no regime democrático.

3 A abordagem societal - ou da sociologia política - valoriza os atores sociais, suas posições na estrutura social, suas identidades, seus vínculos de classe e trajetórias, entendendo que eles desempenham papel importante nos processos políticos formais. Portanto, relações sociais, culturais e econômicas de: poder, dominação, influência e participação são consideradas fundamentais para compreensão da política. 
stricto sensu das universidades federais brasileiras na área de ciências sociais, a taxa foi de 80\% (GeoCapes, 2004-2012 apud Souza et al., 2018). Nesse período, o número de professores doutores vinculados à Pós-Graduação stricto sensu nessas instituições, na área de ciências sociais, cresceu 100,70\%. Quanto à produção científica das universidades federais brasileiras, na área de ciências sociais, a evolução foi da ordem de 336,90\% entre 20042012 (WoS, 2004-2012 apud Souza et al., 2018). Esses números sugerem o crescimento também na área de ciência política.

Os periódicos foram escolhidos pela importância que têm no campo, segundo avaliação feita pela Coordenação de Aperfeiçoamento de Pessoal de Nível Superior $(\mathrm{CAPES})^{4}$. Eleger esse objeto propicia um refinamento do olhar, pois ilumina parcela mais específica e especializada dos agentes que atuam na disciplina. Trata-se de complementar os estudos recentes sobre a produção em periódicos de Ciência Política (Marques, 2007; Oliveira; Nicolau, 2014; Marques; Machado, 2014; Leite, 2015). O corpus compreende duas partes, uma quantitativa ${ }^{5}$ e outra qualitativa. Nesta pesquisa, o objetivo é olhar com atenção os artigos que tratam especificamente da relação entre democracia e desigualdade. Existem diferenças significativas na produção científica dos doutores em Ciência Política em relação aos demais agentes da área? A hegemonia institucionalista também pode ser constatada na produção desse grupo? As análises sobre democracia e desigualdade operam fora dessa chave hegemônica?

Em seguida, analisamos a percepção dos editores dos periódicos. Foram realizadas entrevistas em profundidade com dois editores de cada um dos sete periódicos nacionais, com exceção da Opinião Pública e da Lua Nova, pois, nesses casos, ouvimos apenas um dos editores. A coleta se deu entre 2014 e 2015, por meio de um roteiro com questões abertas $^{6}$.

Os editores ocupam posição estratégica na área, estão expostos às pressões do campo e discutem os critérios que orientam o perfil de cada periódico. Qual a percepção dos editores sobre a tensão que marca o campo da Ciência Política? Do ponto de vista deles, os periódicos cumprem qual papel nas disputas internas da área?

$\mathrm{Na}$ primeira parte, apresentaremos análises sobre a formação do campo. O objetivo é mostrar que nesta seara também existem controvérsias sobre a hegemonia institucionalista. A análise quantitativa dos artigos publicados pelos doutores em Ciência Política está na segunda parte, em que procuramos comparar os dados com a produção geral da área.

4 O sistema Qualis adota de critérios para hierarquizar os periódicos, que são definidos pelos comitês de área de conhecimento, formados por professores oriundos dos programas de pós-graduação.

5 O banco de dados contém títulos e palavras-chave de 1505 artigos publicados nos sete periódicos entre 2005 e 2014, assim como, os nomes, as instituições de doutoramento, os respectivos cursos e os vínculos institucionais dos autores e coautores destes artigos. Foram selecionados 538 itens publicados por autores e coautores que se doutoraram em Ciência Política no Brasil aos quais se aplicou estatística descritiva.

6 Agradecemos aos editores pela contribuição. Os depoimentos dados pelos editores foram coletados em entrevistas realizadas pelos autores. Os editores concordaram com a publicação dos conteúdos e a identificação dos seus nomes. 
Nessa sessão, também analisamos os artigos que tratam o tema da democracia vinculado ao da desigualdade, pois a relação entre formação social e democracia é ponto nevrálgico do debate. A terceira analisa consideremos a percepção dos editores dos periódicos sobre o atual momento do campo.

\section{Olhares sobre a formação da Ciência Política.}

A autonomização da Ciência Política avançou nos anos 1960-1970 com a implantação de um sistema de pós-graduação junto a delimitação de linhas temáticas; a organização de uma comunidade de profissionais especializados, reunidos em associações e agências capazes de estabelecer os parâmetros do fazer científico; a criação da hierarquia na área com base no mérito e na avaliação da produção por pares (Marenco, 2014). O desenvolvimento de teoria e metodologia autônomas e o surgimento de periódicos são outros elementos desse processo (Leite; Codato, 2013).

A institucionalização de uma disciplina não é mero procedimento técnico. Trata-se de processo em que parâmetros de comportamento, critérios de avaliação e financiamento são estabelecidos, o que pode gerar disputas por hegemonia. A construção das regras do jogo estabelece os limites espaciais e lógicos da disciplina, demarcando o centro e a periferia, o superior e o inferior, no que diz respeito às suas instituições, produções e agentes.

No início da Ciência Política brasileira, pesquisadores frequentaram a academia norteamericana e receberam investimentos da Fundação Ford. Essas experiências valorizaram a pesquisa empírica e os métodos quantitativos avançados (Oliveira, Nicolau, 2014; Reis, 2015). Ficou em segundo plano a abordagem ensaística e relativamente engajada (Marenco, 2014). A afirmação institucional passou pela formatação de uma linguagem comum erguida sobre referenciais considerados seguros e análises rigorosas de objetos claramente identificados (Leite, 2015). Entretanto, Fábio Wanderley Reis (1991, 1993, 1997), Neuma Aguiar (2001) e Gláucio Soares (2005) criticaram o baixo investimento em métodos quantitativos e em estatística sofisticada. Situação que dificultava a delimitação metodológica da disciplina. Esse importante debate teve continuidade nos trabalhos de Ignácio Cano (2012) e Emerson Cervi (2018).

No seu início, a Ciência Política vivenciou a transição da ditadura militar para a democracia, transição que se tornou objeto pelo viés institucionalista, o que gerou controvérsias. A postura que valorizava os pré-requisitos sociais para a construção da democracia foi suplantada por aquela que enfatizava o papel das instituições nesse processo. A perspectiva institucionalista ganhou força na agenda de pesquisa (Limongi et al., 2015). Tratava-se de pensar sobre o incremento institucional antes bloqueado pelo regime totalitário. Tal escolha implicou em dificuldades para explicar a permanência de comportamentos autoritários num contexto institucional democrático. A desvalorização precoce da abordagem societal restringiu as possibilidades de apreensão da complexidade 
sociopolítica (Mussi, 2014; Moisés, 1995; Leite, 2015). As limitações do institucionalismo advinham de uma definição limitada de democracia, adequada à matriz schumpeteriana (Vitullo, 2006).

Mas as interpretações vão além dos posicionamentos dicotômicos. Existem autores que pregam equilíbrio entre as perspectivas. Os achados do institucionalismo devem se somar aos ganhos da abordagem societal. A política não se explica apenas pelo funcionamento das regras institucionais. Por outro lado, a Sociologia Política não deve desprezar o papel das instituições, mas agregar à explicação sobre o poder as práticas sociais e culturais que o envolvem (Perissinotto, 2004).

Outro exemplo de mediação entre os dualismos está na proposição de uma 'democracia pragmática' formulada por Thamy Pogrebinschi (2010). Ela sugere a superação das dicotomias inconsistentes: Estado e sociedade, representação e participação e empírico e normativo. Olhar a democracia pelo viés social não comprometeria a relativa autonomia do político. Novas formas de participação poderiam contribuir para legitimação da representação política ampliada. O próprio fato da experiência participativa se institucionalizar indicaria a presença do político no social e não uma contraposição dos termos envolvidos na equação. Neste sentido, a 'democracia pragmática' propõe a conciliação entre a teoria normativa das abordagens societais e a empiria da perspectiva institucionalista. Essas posturas conciliatórias são manifestações isoladas ou encontram eco nos artigos e depoimentos que compõem a nossa amostra?

Em resumo, para alguns, a adoção do viés institucionalista contribuiu com a demarcação das fronteiras da disciplina sem ferir o pluralismo teórico e metodológico (Marenco, 2014). Para outros, essa hegemonia oferece o risco ao diálogo interdisciplinar e de abandono da abordagem societal (Leite, 2015).

Visando a compreensão desse processo, alguns estudos elegeram como objeto a produção científica publicada em periódicos qualificados, pois esse material passa por importantes filtros institucionais e oferece um retrato dos aspectos da configuração de forças na disciplina.

Os depoimentos dos editores revelam clara percepção do papel estratégico dos periódicos, como na fala de um dos membros da Dados:

A revista científica tem uma função canônica, [...] através da seleção e certificação dos artigos, [ela] vai dizer o que é certo e o que é errado na ciência. [...] os cientistas dizem através do comitê editorial da revista, não é a revista em si, mas as pessoas que julgam os trabalhos da revista. Então, a revista científica acompanha o desenvolvimento de uma comunidade e interage com ela. [...] A revista reflete a produção acadêmica, ela não inventa, ela recebe e filtra. (CHARLES PESSANHA, Editor, Dados, 2014)

A comunidade legitima os periódicos como veículos de divulgação de conteúdos, promoção do debate, mas também como instrumentos de avaliação entre pares. Critério que incide sobre o financiamento dos programas de pós-graduação e, no limite, na justificativa da hierarquia de temas de pesquisa. 
Perspectiva semelhante transparece nas palavras de um dos editores da RSP:

[...] acho que as revistas sofrem um impacto do campo, o nosso caso é muito evidente nesse sentido, mas, ao mesmo tempo, elas conseguem alimentar [o campo]. [...] Se todas as revistas só publicassem o institucionalismo da escolha racional, isso forçaria, enfim, as pessoas a serem só institucionalistas de escolha racional, ou, a não publicar. (RENATO PERISSINOTTO, Editor, RSP, 2015)

A produção em periódicos pode ser, portanto, um bom indicativo sobre a tensão que elegemos como objeto. Por um lado, os artigos publicados preencheram os requisitos definidos nas disputas da área, por outro, eles constituem critério de avaliação dos profissionais e dos programas de pós-graduação aos quais estão vinculados.

O campo da Ciência Política, segundo Leite ${ }^{7}$ (2015), não contempla uma pluralidade, e sim uma hierarquia, cuja hegemonia é da tradição politológica que prima pelo viés institucional, empirista e de métodos quantitativos sofisticados; isso em oposição à tradição societal de corte humanístico, histórico-interpretativo, que prioriza métodos qualitativos (Leite, 2015). O risco desse cenário, de acordo com o autor, é a consolidação de um oficialismo que desvaloriza a análise de objetos de pouca visibilidade, aqueles marcados pela norma e não por regras claramente institucionalizadas. $\mathrm{O}$ próprio tema da democracia sofre uma restrição analítica. Os aspectos informais e normativos que envolvem a democracia, elementos sociocognitivos, são rebaixados na hierarquia do campo, pois são de dificil apreensão pelos métodos científicos consagrados. Para Leite (2015), o principal problema é confundir o que é uma opção resultante das disputas pela construção do campo e de sua autonomia, com a cientificidade propriamente dita.

Preocupada em contribuir com a caracterização do campo das Ciências Sociais, Marques (2007) observou os artigos sobre democracia ${ }^{8}$.A ênfase de grande parte dos artigos analisados recai sobre as instituições e os procedimentos da democracia liberal-pluralista. $\mathrm{O}$ tom adotado pelos autores foi de legitimação desta forma de governo. Na periferia do debate, alguns trabalhos fazem a crítica desse modelo de análise, procurando alternativas conceituais e metodológicas. Neste caso, o olhar prioriza a sociedade elegendo-a como variável explicativa e interveniente da realidade política.

Em trabalho complementar, Marques e Machado (2014) redefinem o objeto que passou a ser a abordagem das Ciências Sociais sobre o conceito de desigualdade e sua interface com o tema da democracia ${ }^{9}$. Os autores partem do pressuposto de que a disputa discursiva que marca a sociedade também envolve a academia. Eles constatam que existe um número significativo de artigos cujo tema é a desigualdade e (ou) a democracia.

7 Leite selecionou a produção de Ciência Política veiculada por 23 revistas no período entre 2010-2012.

8 A autora analisou, para tanto, artigos publicados em três periódicos: RBCS, Dados e Lua Nova; entre 1985 e 2005.

9 Os autores escolheram os mesmos periódicos: RBCS, Dados e Lua Nova; observando as publicações entre 2000 e 2010. 
Entretanto, a desigualdade é mais mencionada que discutida em profundidade. A maioria dos artigos, tampouco, trata com rigor a articulação entre desigualdade e democracia. Segundo os autores, mesmo quando os artigos contam com a participação de cientistas políticos, a frequência da efetiva discussão da desigualdade continua baixa. Eles concluem que o debate entre os pares parece ser escasso e frágil.

Os estudos mencionados indicam a validade da análise da produção em periódicos para apreender aspectos das disputas na Ciência Política. É claro que uma visão mais completa do campo exigiria a ampliação do corpus no sentido de apreender outras dimensões relevantes, tais como: a distribuição de recursos, a ocupação de cargos, o currículo dos cursos de formação, os periódicos periféricos, as publicações em eventos científicos etc. Acreditamos que diferentes esforços de pesquisa podem se complementar no estudo do campo disciplinar. Para cumprir nosso objetivo, mobilizamos dois recursos. Ampliamos o número de revistas e também alargamos o recorte temporal em relação aos estudos de Marques e Machado. E procuramos refinar o olhar qualitativo ao selecionarmos para análise interna os artigos publicados por doutores em Ciência Política que discutem democracia e desigualdade. Quais tendências, verificadas noutros estudos, podem ser confirmadas nessa amostra? Com base nesse mapeamento, é possível identificar mudanças significativas na hierarquia de assuntos? A amostra sobre 'democracia e desigualdade' permite identificar relações entre as concepções de democracia - substancial e formal - e as posições na hierarquia da produção em Ciência Política - hegemônica ou periférica?

\section{A produção dos doutores em Ciência Política sobre 'democracia edesigualdade'.}

\section{Análise quantitativa da produção.}

Vamos observar a produção acadêmica na área limitada aos artigos publicados por doutores, entre 2005 e 2014, nos sete periódicos selecionados.

A proporção de artigos de doutores na área é de um terço da produção selecionada (Tabela 1). As revistas analisadas publicam também sociólogos e antropólogos, portanto, a Ciência Política está bem representada. A RSP se destaca com um número total de artigos relativamente maior, enquanto a $R B C P$ e, particularmente, a BPSR apresentam números menores, mas é preciso considerar que nosso recorte temporal é anterior às suas fundações. A Tabela 1 serve para comparar proporcionalmente o peso da Ciência Política em cada periódico, ainda que tenhamos selecionado somente os artigos de doutores na área - o que corresponde a 538 (35,7\%) artigos do total de 1505. 
Tabela 1- Total da produção dos doutores em CP por periódicos (2005-2014)

\begin{tabular}{|l|c|c|c|c|c|c|}
\hline Periódicos & Qualis & $\begin{array}{c}\text { Ano de } \\
\text { Criação }\end{array}$ & $\begin{array}{c}\text { Admissão } \\
\text { no Scielo }\end{array}$ & $\begin{array}{c}\text { Total de artigos } \\
\text { publicados }\end{array}$ & $\begin{array}{c}\text { Total de artigos publicados } \\
\text { por Doutores em CP (\%) }\end{array}$ \\
\hline Dados & A1 & 1966 & Abr. 1997 & 267 & 108 & 40,4 \\
\hline Lua Nova & A2 & 1984 & Jul. 2002 & 220 & 65 & 29,5 \\
\hline RBCS & A1 & 1986 & Out. 1988 & 265 & 53 & 20,0 \\
\hline RSP & A2 & 1993 & Fev. 2002 & 342 & 116 & 33,9 \\
\hline Op. Pública & A1 & 1993 & Mar. 2003 & 178 & 100 & 56,1 \\
\hline BPSR & A2 & 2007 & Ago. 2013 & 87 & 45 & 51,7 \\
\hline RBCP & B1 & 2009 & Jul. 2012 & 146 & 51 & 34,9 \\
\hline Total & & & $\mathbf{1 5 0 5}$ & $\mathbf{5 3 8}$ & $\mathbf{3 5 , 7}$ \\
\hline
\end{tabular}

Fonte: Os autores.

Os textos dos doutores não estão excessivamente concentrados. Entretanto, a Opinião Pública e a BPSR se destacam proporcionalmente com índices acima de 50\% de artigos de doutores em Ciência Política, a Dados vem logo a seguir com 40\%. Os temas que predominam no atual mainstream da Ciência Política brasileira são publicados majoritariamente na BPSR e na Dados (Leite, 2015), conforme o Quadro 1 abaixo ${ }^{10}$.

Quadro 1

\begin{tabular}{|c|c|c|c|}
\hline PERIÓDICOS & ABORDAGENS & $\begin{array}{c}\text { CLASSES DE } \\
\text { ABORDAGENS }\end{array}$ & ÁREAS TEMÁTICAS \\
\hline BPSR & Neoinstitucionalismo & Politológicas & $\begin{array}{c}\text { Desempenho das } \\
\text { instituições políticas }\end{array}$ \\
\hline Dados & Neoinstitucionalismo & Politológicas & $\begin{array}{c}\text { Desempenho das } \\
\text { instituições políticas }\end{array}$ \\
\hline Lua Nova & $\begin{array}{c}\text { Hermenêutica;Teoria } \\
\text { Política moderna }\end{array}$ & Idealistas; político-teóricas & $\begin{array}{c}\text { Teoria política, } \\
\text { análise de conceitos e } \\
\text { história das ideias }\end{array}$ \\
\hline Opinião Pública & Culturalismo; & Subjetivistas; culturalista & $\begin{array}{c}\text { Valores, atitudes, } \\
\text { participação e política }\end{array}$ \\
\hline RBCS & Heterogênea & Históricas & $\begin{array}{c}\text { Estado, sociedade e } \\
\text { políticas de governo }\end{array}$ \\
\hline RSP & Heterogênea; elites & $\begin{array}{c}\text { Sociológicas/ } \\
\text { econ.; históricas }\end{array}$ & $\begin{array}{c}\text { Estado, sociedade e } \\
\text { políticas de governo }\end{array}$ \\
\hline
\end{tabular}

Fonte: (Leite, 2010).

10 Assim como Leite (2015), Lilian Oliveira e Jairo Nicolau (2014) atestam o predomínio de abordagens institucionalistas politológicas no campo da Ciência Política e, particularmente, nos periódicos Dados e BPSR. Os autores trabalharam com 858 artigos publicados em cinco periódicos entre 1966 e 2013. 
Podemos concluir que a BPSR e a Dados são hegemônicas também na publicação de artigos dos doutores na disciplina (Tabela 1). Quanto ao baixo desempenho da RBCS neste quesito, ele pode ser explicado por ser um periódico que acolhe várias temáticas e disciplinas.

A Tabela 2 mostra que $400(74,3 \%)$ do total de 538 artigos foram publicados por autores ou coautores que se doutoraram no Brasil e, majoritariamente, em um dos cinco programas de pós-graduação públicos em Ciência Política localizados nas regiões Sudeste e Sul, são eles: Universidade de São Paulo (USP), Universidade Estadual de Campinas (Unicamp), Instituto Universitário de Pesquisas do Rio de Janeiro/Instituto de Estudos Sociais e Políticos (IUPERJ/IESP), Universidade Federal de Minas Gerais (UFMG) e Universidade Federal do Rio Grande do Sul (UFRGS) ${ }^{11}$. Significa que a expansão do sistema de pós-graduação em Ciência Política não refletiu significativamente diversificação da publicação, certamente por ser um fenômeno novo.

Tabela 2 - Produção dos doutores em Ciência Política por IES (2005-2014)

\begin{tabular}{|c|c|c|c|c|}
\hline \multirow[b]{2}{*}{ Periódicos } & \multirow[b]{2}{*}{$\begin{array}{l}\text { Total de artigos } \\
\text { publicados }\end{array}$} & \multicolumn{2}{|c|}{ Diplomados no Brasil } & \multirow[b]{2}{*}{$\begin{array}{l}\text { Diplomados em } \\
\text { IES estrangeira }\end{array}$} \\
\hline & & $\begin{array}{l}\text { USP, UNICAMP } \\
\text { IUPERJ-IESP } \\
\text { UFMG, UFRGS }\end{array}$ & $\begin{array}{c}\text { UFSCar, UFPE } \\
\text { UnB, UFSC } \\
\text { PUC-SP }\end{array}$ & \\
\hline Dados & 108 & 84 & 1 & 23 \\
\hline Lua Nova & 65 & 38 & 1 & 26 \\
\hline$R B C S$ & 53 & 40 & 4 & 9 \\
\hline$R S P$ & 116 & 81 & 9 & 26 \\
\hline Op. Pública & 100 & 65 & 3 & 32 \\
\hline BPSR & 45 & 35 & 4 & 6 \\
\hline$R B C P$ & 51 & 31 & 4 & 16 \\
\hline \multirow{2}{*}{ Total } & \multirow{2}{*}{538} & $374(69,5 \%)$ & $26(4,8 \%)$ & \multirow{2}{*}{$138(25,6 \%)$} \\
\hline & & \multicolumn{2}{|c|}{$400(74,3 \%)$} & \\
\hline
\end{tabular}

Fonte: Os autores.

A Tabela 3 apresenta a distribuição dos artigos por programas de pós-graduação cursados pelos autores e coautores. Ela também detalha o cruzamento deste dado com os periódicos de publicação. Existe equilíbrio entre os novos programas (Unicamp e UFMG). É ratificada a concentração na USP e no IUPERJ/IESP que respondem por 278 artigos (74,3\%). A RSP se destaca na publicação de artigos de doutores vindos da USP, e a Dados é hegemônica na divulgação daqueles oriundos do IUPERJ/IESP.

11 Esclarecemos que retiramos aqueles artigos cujo doutorado dos autores foi realizado na: UFSCar, UnB, UFPE, UFSC e PUC-SP, pois eram pouco representativos, sendo assim chegamos à amostra de 374 artigos. 
Tabela 3 - Produção nos periódicos por IES de doutoramento dos (co)autores (2005 -2014)

\begin{tabular}{|c|c|c|c|c|c|c|}
\hline \multirow{2}{*}{ Periódico } & \multicolumn{6}{|c|}{ Programa de Pós-Graduação em Ciência Política cursado pelos (co)autores } \\
\cline { 2 - 7 } & USP & IUPERJ/IESP & UFRGS & UNICAMP & UFMG & Total \\
\hline Dados & 26 & 42 & 7 & 4 & 5 & 84 \\
\hline Lua Nova & 24 & 8 & 4 & 1 & 1 & 38 \\
\hline RBCS & 16 & 13 & 4 & 5 & 2 & 40 \\
\hline RSP & 39 & 20 & 11 & 8 & 3 & 81 \\
\hline Op. Pública & 27 & 21 & 9 & 3 & 5 & 65 \\
\hline BPSR & 12 & 15 & 6 & 2 & 0 & 35 \\
\hline RBCP & 7 & 8 & 8 & 4 & 4 & 31 \\
\hline Total & 151 & 127 & 49 & 27 & 20 & 374 \\
\hline
\end{tabular}

Fonte: Os autores.

A Tabela 4 mostra a frequência de termos encontrados nos títulos dos artigos. Confirma-se a hegemonia do tema 'instituições políticas'. É interessante observar que dos 374 artigos da amostra, 155 (41\%) mencionam no título algum tipo de instituição política. Definitivamente os doutores reproduzem a hierarquia de assuntos que marca o campo. A superioridade desse tema em relação ao segundo que mais aparece, democracia, é maior que o triplo, ou seja, $41 \%$ de frequência contra $12 \%$.

Tabela 4: Presença das temáticas nos títulos dos artigos (2005 -2014)

\begin{tabular}{|c|c|c|}
\hline Termos presentes nos títulos dos artigos & Frequência & Porcentagem \\
\hline Democracia ou correlatos12 & 46 & 12,3 \\
\hline Instituições políticas13 & 155 & 41,4 \\
\hline Outras temáticas14 & 173 & 46,3 \\
\hline Total & 374 & 100 \\
\hline
\end{tabular}

Fonte: Os autores.

A Tabela 5 cruza as temáticas dos artigos pelos periódicos. Os números revelam uma enfática hegemonia do tema instituições políticas em relação ao assunto democracia, principalmente na Dados (45,2\% contra 9,5\%), e na BPSR (40\% contra 9,5\%). A vocação desses veículos se confirma também no caso específico da publicação dos doutores.

12 Termos correlatos: democracias andinas; construção democrática; discurso democrático; política externa democrática; legitimidade democrática; instituições democráticas; crítica democrática; democratização; Brasil democrático; democracias americanas e teoria democrática.

13 Foram identificados 155 artigos que possuem no título uma das seguintes instituições políticas: partidos e sistemas partidários (nacionais e subnacionais); eleições e sistemas eleitorais (comportamento político e eleitoral); Poder Legislativo e sua relação com o Poder Executivo (Câmara dos Deputados, Senado, Congresso Nacional); Poder Judiciário e federalismo.

14 Pertencem ao grupo Outras temáticas os artigos sobre teoria política, pensamento social e político, movimentos sociais, instituições participativas, políticas públicas, neoinstitucionalismo e outros assuntos. 
A Opinião Pública surpreende, pois, apesar de nela predominar a abordagem culturalista subjetivista (Quadro 1), quando se trata da publicação dos artigos dos doutores em Ciência Política, ocorre elevada vantagem do tema instituições $(66,1 \%)$ sobre o assunto democracia (12,3\%). O Gráfico 1, mais abaixo, representa essas informações. Nele, a Opinião Pública está mais próxima do tema instituições políticas do que a BPSR e isso se deve, em parte, ao número total de artigos de cada periódico. A RSP, considerada heterogênea quanto à publicação de cientistas políticos em geral, no que se refere aos doutores, também divulgou mais artigos com temáticas institucionalistas, com uma diferença significativa em relação à democracia, neste caso as cifras são de 35,8\% contra 8,6\%. Entretanto, o seu caráter heterogêneo se confirma quanto ao grande número de artigos sobre 'outros temas', o que pode ser visualizado tanto no Gráfico 1 quanto na Tabela 5.

A Lua Nova é a única revista em que a publicação de artigos com o tema democracia foi maior do que instituições, ainda que a diferença seja pequena: em números absolutos 8 contra 7. Ela aparece no Gráfico 1 próxima do tema democracia. A RBCP, de caráter pluralista, e a RBCS, de perfil heterogêneo, também publicaram mais artigos de doutores com o tema instituições do que com o assunto democracia, o que confirma a hegemonia institucionalista na área também para este segmento.

Tabela 5 - Presença das temáticas nos títulos dos artigos por periódico

\begin{tabular}{|l|c|c|c|c|c|c|c|c|c|}
\hline $\begin{array}{c}\text { Palavra presente } \\
\text { nos títulos } \\
\text { dos artigos }\end{array}$ & \multicolumn{10}{|c|}{ PADOS } & $\begin{array}{c}\text { LUA } \\
\text { NOVA }\end{array}$ & RBCS & $\boldsymbol{R S P}$ & $\begin{array}{c}\text { Opinião } \\
\text { Pública }\end{array}$ & BPSR & RBCP & Total & $\%$ \\
\hline $\begin{array}{l}\text { Democracia ou } \\
\text { termos correlatos }\end{array}$ & 8 & 8 & 8 & 7 & 8 & 2 & 5 & 46 & 12,3 \\
\hline $\begin{array}{l}\text { Instituições } \\
\text { políticas }\end{array}$ & 38 & 7 & 12 & 29 & 43 & 14 & 12 & 155 & 41,4 \\
\hline Outras temáticas & 38 & 23 & 20 & 45 & 14 & 19 & 14 & 173 & 46,3 \\
\hline Total & 84 & 38 & 40 & 81 & 65 & 35 & 31 & 374 & 100 \\
\hline
\end{tabular}

Fonte: Os autores.

O cruzamento do tema dos artigos com a procedência dos autores e coautores quanto ao programa no qual se doutoraram (Tabela 6) indica que as maiores vantagens do tema instituições sobre democracia estão, proporcionalmente, na publicação daqueles doutores oriundos da UNICAMP, do IUPERJ/IESP e da USP. Quanto às publicações dos doutores formados na UFRGS e na UFMG, a vantagem se mantém, mas em proporções menores. 
Tabela 6 - Presença das temáticas nos títulos dos artigos por programa de pós-graduação.

\begin{tabular}{|l|c|c|c|c|c|c|}
\hline \multirow{2}{*}{$\begin{array}{c}\text { Temas presentes } \\
\text { nos títulos dos } \\
\text { artigos }\end{array}$} & \multicolumn{5}{|c|}{$\begin{array}{c}\text { Programa de pós-graduação em CP cursado pelos } \\
\text { (co)-autores }\end{array}$} & \multicolumn{1}{c|}{} \\
\cline { 2 - 7 } & USP & IUPERJ/IESP & UFRGS & UNICAMP & UFMG & Total \\
\hline $\begin{array}{l}\text { Democracia ou } \\
\text { termos correlatos }\end{array}$ & 19 & 13 & 8 & 1 & 5 & $46(12,3 \%)$ \\
\hline $\begin{array}{l}\text { Instituições } \\
\text { políticas }\end{array}$ & 56 & 62 & 18 & 10 & 9 & $154(41,2 \%)$ \\
\hline Outras temáticas & 76 & 52 & 23 & 16 & 6 & $174(46,5 \%)$ \\
\hline Total & 151 & 127 & 49 & 27 & 20 & 374 \\
\hline
\end{tabular}

Fonte: Os autores.

O Gráfico 2 indica uma grande distância da $R B C P$ dos programas de pós-graduação do Rio de Janeiro (IUPERJ/IESP) e de São Paulo (USP), ou seja, ela publica poucos artigos dos doutores oriundos dessas instituições. Por sua vez, a Dados está muito próxima do IUPERJ/IESP, o que pode indicar uma endogenia, com o periódico publicando preferencialmente artigos de doutores formados naquela instituição.

Gráficos de correspondência entre periódicos, temas e programas de pós-graduação $(\mathrm{N}=374)$.

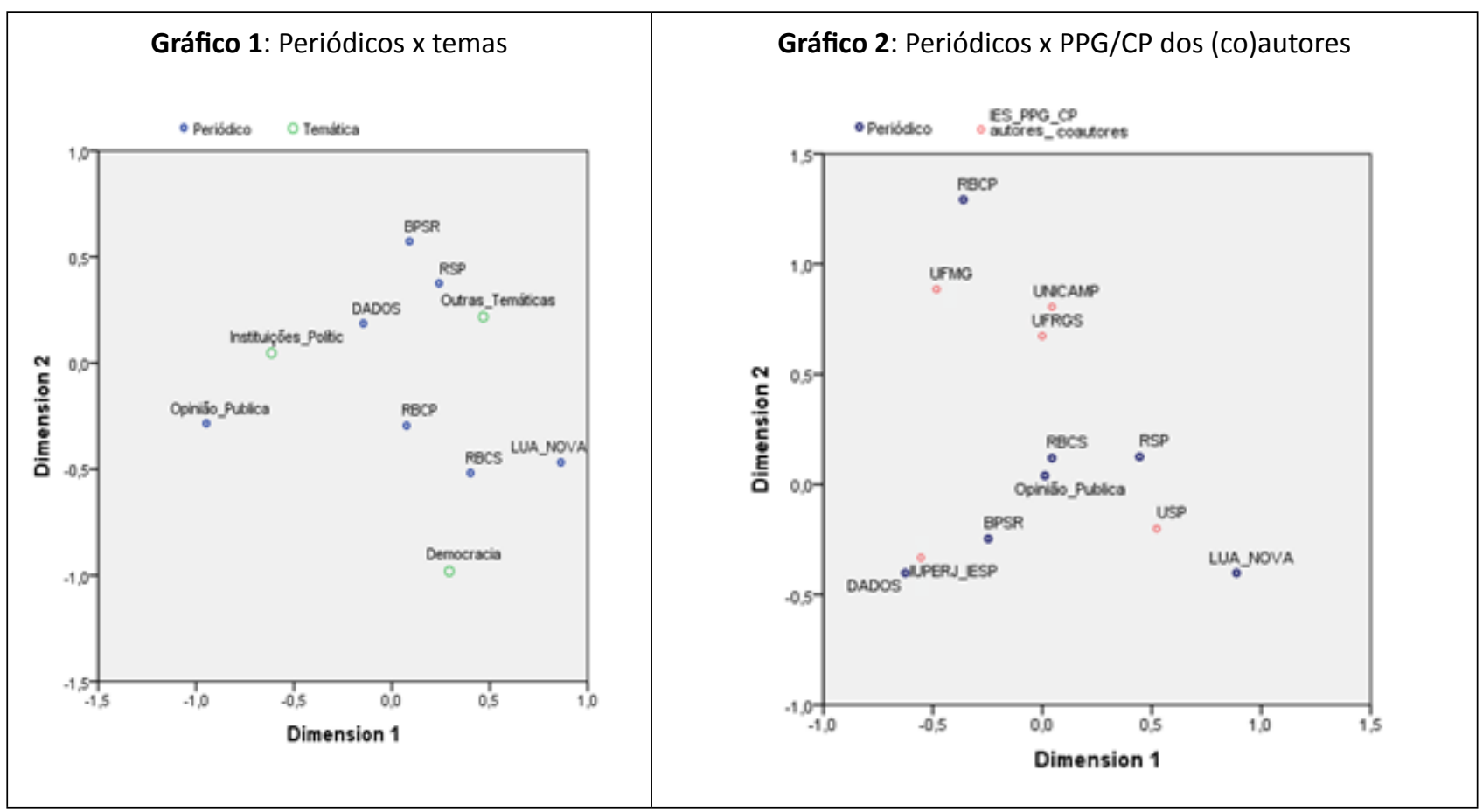

Fonte: Os Autores.

Em resumo, vimos nesta sessão, através de diferentes dados quantitativos, que a hegemonia do institucionalismo se confirma também quando analisada apenas a produção dos doutores em Ciência Política. A maior incidência do tema instituições políticas sobre democracia perpassa quase todos os periódicos, mas está mais evidenciada na Dados e na BPSR, com destaque também para a Opinião Pública.Vejamos o que os dados qualitativos apresentam. 


\section{Análise qualitativa dos artigos que vinculam democracia e desigualdade.}

$\mathrm{Na}$ amostra de 374 artigos, 46 deles (12\%) possuem no título a palavra democracia ou correlatos. Indícios de institucionalismo aparecem noutros termos combinados com democracia, tais como: eleições, partidos, lei de ferro, instituições, constituição, constituinte, constitucionalistas, Judiciário e reforma política. Logo, quando os doutores em Ciência Política tratam do assunto democracia, tende a se repetir o padrão geral da área quanto à abordagem predominante.

Para alguns, o predomínio institucionalista reside na mudança de percepção dos anos 1990: “a noção de que o Brasil se via em meio a uma crise de governabilidade insuperável vai sendo deixada para trás [...] o foco das análises passa a ser o funcionamento da democracia brasileira" (Limongi et al., 2015, p. 23). Trata-se de uma justificativa parcial, pois não existe um vínculo essencial entre a preocupação com o "funcionamento da democracia" e a preponderância do olhar sobre as instituições.

Com o objetivo de mapear a disputa em tela, realizamos um recorte a mais na amostra de 46 textos cujo tema é a democracia. Selecionamos os artigos que efetivamente discutem o assunto democracia, mas em articulação com algum tipo de desigualdade. Tal escolha se justifica por permitir a observação de um subtema que a princípio é mais afinado com a abordagem societal, pois olha a democracia para além das suas instituições tipicamente políticas, valorizando sua relação com a formação social e priorizando as desigualdades sociais, econômicas e/ou culturais. Uma vez mais o peso do viés institucionalista pode ser observado, pois são apenas nove os artigos que propõem tal recorte.

Vejamos nesses nove artigos o tipo de análise sugerida.A ênfase recai sobre a democracia substancial, própria da abordagem societal ou a preocupação com a democracia formal se faz presente? O quê esses nove artigos revelam sobre a tensão em tela?

Sobre os veículos de divulgação dos nove artigos selecionados, eles se concentram na Dados e na Opinião Pública. Na RSP, aparece apenas um artigo. Cabe destacar que no caso da Dados, revista que adota uma linha institucionalista, um de seus editores, Breno Bringel (2014), enfatiza justamente a articulação entre democracia e desigualdade como preocupação temática da revista, mas quando a produção é sociológica:

no que se refere à agenda mais temática [...] eu acho que a Dados sempre teve uma grande preocupação que é pensar o Brasil [...] pensar a democracia no Brasil. [...] mas, não só, simplesmente, a construção das instituições democráticas. Também $[\ldots]$ as várias questões associadas ao sistema de partido, ao sistema político, a alguns atores sociopolíticos específicos, como as elites políticas. [...] não é casual que as desigualdades, por exemplo, seja um dos principais temas de discussão da produção sociológica presente na 'Dados'. (BRENO BRINGEL, Editor, Dados)

A fala atesta a abertura do periódico a abordagens societais, mas também sugere que a articulação entre democracia e desigualdade escapa às fronteiras da Ciência Política construídas, em grande medida, pela hegemonia institucionalista. 
Dos nove artigos em tela, seis enfatizam a desigualdade socioeconômica. Ou seja, do seu lugar periférico, eles propõem um olhar diferente do hegemônico ao apontarem a desigualdade socioeconômica como variável que deve ser levada em consideração na análise da democracia ${ }^{15}$. É importante realçar que, desse ponto de vista, as investigações sobre esse sistema político que restringem o olhar às suas instituições formais perdem autenticidade teórica, assim como a própria democracia formal é menos legítima que a substancial.

Agrupar os artigos em função do tipo de preocupação explicitada, normativa/ prescritiva ou analítica/descritiva, pode ser útil para compreensão do local que efetivamente ocupam no debate atual sobre a Ciência Política. Mobilizando esse critério, encontramos seis artigos que externam preocupação normativa, número que não surpreende pela própria articulação temática que se propõem tratar: democracia e desigualdade. Nesses artigos, são discutidas as desigualdades racial, informacional e socioeconômica. A tese presente neles é a de que a desigualdade oferece barreiras para o funcionamento da democracia, comprometendo sua legitimidade e dificultando sua consolidação. $\mathrm{O}$ diagnóstico é válido, segundo os autores dos artigos, para a democracia substancial, mas também para a formal. Nesse sentido, um dos artigos conclui que "[...] dissociar a democracia da igualdade material é, no mínimo, problemático, na medida em que essa última constitui um patamar sine qua non para o pleno exercício dos direitos políticos" (Moreira, 2014, p. 318-319).

Existe a preocupação com os efeitos práticos do discurso dominante na Ciência Política brasileira, pois ele "termina consagrando a limitação da democracia exclusivamente à esfera das instituições oficiais, legitimando uma noção de democracia que não guarda relação com os necessários e impostergáveis processos de transformação social [...]" (Vitullo, 2006, p. 354). Fica patente o mal-estar com a proximidade entre democracia formal e Ciência Política institucionalista. Os doutores que escrevem sobre democracia e desigualdade nos periódicos selecionados enfatizam a democracia substantiva, denunciando os limites da abordagem sobre democracia formal, objeto por excelência da Ciência Política institucionalista.

Entretanto, o outro lado da tensão também transparece na amostra, ou seja, a defesa da importância das instituições quando fatores externos à política não colaboram com a democracia: "a sobrevivência de uma democracia não depende unicamente do desenvolvimento socioeconômico atingido, senão do concurso de condições e instituições" (Lopes, 2007, p. 646). O entendimento é de que as instituições formais importam na análise da democracia, uma vez que são elas que resistem aos golpes próprios de contextos sociais e econômicos desfavoráveis.

A relação entre democracia formal e substantiva é complexa tanto em termos concretos quanto teóricos. Moisés (2010) descreve um estudo que confronta as duas dimensões da democracia com base em surveys realizados entre 1989 e 2006. O intuito era saber como os entrevistados definem democracia e também, no caso de países como o Brasil,

15 A presença majoritária desse tipo de desigualdade foi apontada também por Marques e Machado (2014). 
cujas estruturas econômicas e sociais são caracterizadas por profundas desigualdades, se os indivíduos consultados expressariam preferências por conteúdos relacionados com suas carências materiais, em detrimento de definições relativas aos valores e aos procedimentos típicos da democracia.

Dado isso, este estudo conclui que a maior parte dos brasileiros foi capaz de definir a democracia mobilizando duas de suas dimensões mais importantes: liberdades fundamentais e procedimentos institucionais, combinando, portanto, uma ideia normativa ligada aos princípios democráticos com outra de natureza prática, relativa ao desempenho das instituições. Já a dimensão social ou a substantivação da democracia teve pouco peso no conjunto das respostas oferecidas pelos entrevistados. Outro resultado apontado neste artigo é o de que os entrevistados se mostraram desconfiados em relação às instituições democráticas em geral (Moisés, 2010). Ou seja, os princípios democráticos podem não sofrer diretamente com o descrédito da população em contextos de desigualdade, mas as instituições democráticas tendem a ser mais vulneráveis. Esse tipo de dado parece apontar para a necessidade de um olhar duplo e equilibrado da Ciência Política, sobre a sociedade e as instituições. Olhar importante tanto para o desenvolvimento da disciplina quanto para o avanço da própria democracia.

O descrédito das instituições democráticas também pode advir da condição precária do sistema de mídia em sua relação com o sistema político. Segundo Azevedo, nosso contexto oferece um "sistema de mídia com baixa diversidade externa e sem um jornalismo político e/ou partidário expressivo no plano nacional que ofereça ao leitor perspectivas políticas competitivas" (Azevedo, 2006, p.109).

Desse ponto de vista, a relação entre as dimensões política e jornalística tem reflexos sobre as instituições democráticas, seu funcionamento e também sobre a percepção que os cidadãos têm delas. Portanto, é legítimo e necessário à Ciência Política se ocupar desta interação entre política e sociedade.

A mesma perspectiva é adotada no artigo que valoriza o debate sobre reconhecimento na esfera pública ao tratar a questão racial. Os autores sublinham a importância da política pública de cotas como mecanismo de desconstrução do racismo e de aprofundamento da democracia (Avritzer; Gomes, 2013). O tema das políticas públicas parece ocupar espaço estratégico na interação entre sociedade e política, talvez se oferecendo como exemplo de equilíbrio entre as abordagens societal e politológica.

Sem ênfase normativa, outros três artigos abordam as desigualdades racial e socioeconômica. O primeiro deles aponta, com base em pesquisas de opinião realizadas em 2009 e 2010, que 97,7\% dos entrevistados, pertencentes às elites brasileiras, afirmam que a democracia é sempre a melhor forma de governo, em qualquer circunstância, e também mostra que para 71\% dos entrevistados a "democracia formal" é insuficiente para a solução dos problemas sociais da América Latina (Balbachevsky; Holzhacker, 2011). O próprio problema proposto pelos autores indica a valorização da democracia substantiva frente à formal e os dados encontrados referendam a perspectiva adotada. 
Outro artigo relaciona os programas de liberalização econômica com o contexto crítico experimentado pela democratização naVenezuela, no Peru, no Equador, na Bolívia e na Colômbia. Diante da dicotomia entre mercado e Estado, o autor coloca a democracia no centro, ao que parece como condição de superação da própria tensão. Portanto, tratase de mais um artigo que não se propõe a olhar as instituições democráticas internamente, ao contrário, valoriza a interação entre as políticas adotadas, a economia e a sociedade (Coutinho, 2006).

Com um olhar retrospectivo, outro artigo entende que o dilema entre democracia formal e substantiva é antigo no Brasil. Nele, o autor contrapõe os discursos de modernização democrática de dois importantes personagens brasileiros: Rui Barbosa e Joaquim Nabuco. Barbosa propôs reformas políticas com base na concepção liberal formalista de democracia, aderindo à perspectiva das elites agrárias. Nabuco, por sua vez, defendeu reformas sociais típicas de uma concepção mais substantiva de democracia, aliando-se ao projeto de emancipação dos escravos. Segundo o autor, o resultado dessa disputa foi que o país trilhou o caminho proposto por Rui Barbosa (Lynch, 2008).

O conjunto dos nove artigos mostra uma pluralidade temática e metodológica. A maioria adotou um tom normativo, abraçando a democracia substantiva e se posicionando criticamente à abordagem formal da democracia proposta pelos institucionalistas. Mas a tensão entre as duas perspectivas se fez presente com reconhecimentos pontuais sobre a importância das instituições para a democracia. Alguns dos artigos apontam de forma indireta para a necessidade de superação das dicotomias. Arriscamos dizer que conceitos como 'políticas públicas' e 'democracia' poderiam servir de pontes conceituais úteis ao equilíbrio entre as abordagens politológicas e societais, ou seja, contra a hegemonia institucionalista.

Vejamos o olhar dos editores, eles ocupam posições estratégicas na elaboração e (ou) aplicação dos critérios que hierarquizam a produção científica. A este respeito, dois editores (da RSP e da Lua Nova) se manifestaram:

O editor não é o cara que senta, lê o artigo e fala: vai publicar. Em alguns aspectos ele é o despachante: ele vai olhar o conteúdo do artigo, vai olhar se tem aderência, se é um artigo acadêmico, se não, já recusa. [...] Feito isso, vai para o parecerista. [...] Ele tem que pensar nas competências das pessoas que vão avaliar [...]. Então tem tanto essa dimensão do despachante, como do editor mesmo. (PAULO COSTA, Editor, RSP, 2015)

... todo mundo quer saber quem é o editor da revista [...], porque afinal de contas ele tem poder sobre o que vai sair [...]. Eu que sou editor, posso dizer que é realmente um trabalho dificil [...], você tem que ser uma espécie de empresário acadêmico. (CÍCERO ARAUJO, Editor, Lua Nova, 2015)

Os depoimentos revelam o papel decisivo do editor na tomada de decisão sobre o que entra ou não na revista, em algum grau ele participa da conformação do campo e sofre as pressões deste processo. 
Um dos editores da Dados expõe a preocupação com a interferência de subjetividades na seleção dos artigos:

Um editor científico não pode ter preconceitos a metodologias e a teorias. Então, ele tem que ser uma pessoa justa. Por quê? Porque você não pode pedir uma avaliação num artigo esperando de antemão que aquele artigo vai ser ajudado ou prejudicado. Qual é a tarefa principal de um editor científico? É exatamente fazer com que um trabalho só entre ou não na revista que está sob sua responsabilidade por critério acadêmico, científico. [...] Então é necessário que você tenha uma boa dose de conhecimento para dialogar com os artigos. (CHARLES PESSANHA, Editor, Dados, 2014)

Pessanha (2014) afirma que o periódico acompanha os critérios determinados pela própria comunidade. Neste sentido, o editor é uma espécie de agente que, por causa de sua trajetória, do respeito adquirido na área e, especialmente, de seus pares, é selecionado para aplicar o modelo de cientificidade considerado legítimo pelo campo. Essa situação confere ao editor posição privilegiada de tomada de decisão e de observação das disputas e tendências. Ouvir os editores é importante para mapear a hegemonia institucionalista e a resistência societal.

\section{A percepção dos editores sobre a Ciência Política no Brasil}

Abordaremos neste item a percepção dos editores dos sete periódicos por nós selecionados a respeito de assuntos que evidenciam as disputas na Ciência Política brasileira: perfil teórico-metodológico da disciplina, formas de produção, publicação, avaliação e financiamento; assim como, seus limites e desafios.

Para Perissinotto (2015), da RSP, “a Ciência Política, pela hiperespecialização, perdeu o Estado como objeto; [...] deixou de lado o problema dos padrões de funcionamento do Estado brasileiro e suas origens históricas, [também] o diálogo com a história”. Talvez, por isso, segundo Gurza Lavalle (2015), "a Ciência Política ainda não conseguiu produzir uma boa síntese... interpretativa, plausível... da transformação do Estado brasileiro e da sociedade brasileira no pós-transição". Segundo ele, para isto, a Ciência Política precisa ser capaz de colocar atores sociais na cena, coisa que ela não está interessada. Afinal, isso não é um tipo "de problema que um institucionalista preocupado com partidos vai se colocar", complementa o editor da RBCS. Os editores expressaram acima visões coerentes com o perfil dos periódicos que dirigem, qual seja ele, de abordagens heterogêneas, históricosociológicas e com equilíbrio entre os temas do Estado e da sociedade. As falas evidenciam que a tensão entre abordagens institucionais e societais está na agenda dos editores. 
Apesar dos problemas apontados, Perissinotto reconhece as contribuições da Ciência Política para o campo, tal como o conceito de presidencialismo de coalizão ${ }^{16}$ criado pelo institucionalista Sérgio Abranches. Os editores da Dados e da BPSR, cujo perfil das abordagens é neoinstitucionalista e politológica, reiteram a importância desse conceito. Confirma-se, portanto, a tensão entre o reconhecimento da importância da vertente politológica e a crítica à sua hegemonia em função do risco que oferece, qual seja, o fechamento analítico da disciplina.

André Marenco ${ }^{17}$ (2015) aponta para a necessidade de a Ciência Política brasileira produzir novas contribuições. Para ele, um dos caminhos é a investigação sobre "como as instituições se formam e que tipo de configuração institucional produz equilíbrio". Outro ponto polêmico mencionado por Marenco diz respeito ao sistema de avaliação da CAPES. De acordo com ele, trata-se de auferir a qualidade, e não mensurar a quantidade da produção científica. Em seu entendimento, a classificação da produção pelo Qualis, hierarquização com base em critérios de qualidade, é fundamental para a autonomia e o fortalecimento da área. Entretanto, é preciso reconhecer que esse processo não é simplesmente técnico, não se trata apenas da aplicação de critérios científicos ao campo, pois envolve uma disputa pela definição dos próprios critérios. Trata-se da luta pela hegemonia que define a distribuição dos valores materiais e simbólicos na disciplina. Esse jogo transparece na afirmação do editor da Lua Nova:

Se você pensar que [...] os constrangimentos são feitos por pessoas [...] [e que] se a comunidade [acadêmica] tem uma predominância numa direção ou noutra, isso constrange $[\ldots]$ o conjunto. Constrange o conjunto porque $[\ldots][\ldots]$ se você quiser usar a linguagem dos institucionalistas: premia e pune. (CÍCERO DE ARAUJO, Editor, Lua Nova, 2015)

Adrián Lavalle, editor da RBCS, chama atenção para o alcance desse tipo de avaliação e classificação ao lembrar que o que se publica nos periódicos mais bem conceituados representa uma parte muito pequena do campo. Conforme Lavalle (2015):

Há indícios de que o campo tem se deslocado no sentido de uma maior sofisticação metodológica [...]. Se você olhar para o Qualis A1 e A2, você está selecionando uma parte muito pequena do campo [...]. A questão é saber se aquilo que a gente olha, quando olha pra essas revistas, corresponde a uma tendência mais geral no campo, eu tendo a acreditar que essa tendência existe, mas não temos evidências suficientes pra entender quão grande ela é, quão enraizada ela está e se ela de fato está presente na maior parte das instituições de Ciência Política no país. (ADRIÁN GURZA LAVALLE, Editor, RBCS, 2015)

16 De forma breve, esse conceito explicita o desenho político-institucional brasileiro, no qual o poder executivo exerce sua influência sobre o legislativo formando uma coalizão de partidos, baseada mais na distribuição de cargos do que em princípios ideológicos e programáticos, com o objetivo de viabilizar a governabilidade.

17 André Luiz Marenco dos Santos, coordenador da Área de Ciência Política e Relações Internacionais da CAPES, também foi entrevistado para esta pesquisa. 
A própria transição ocorrida na história da $R S P$, narrada por um de seus editores, sugere que o arranjo hegemônico que se afirmou na trajetória da disciplina interferiu no espaço destinado aos artigos, pois:

[A RSP] começou basicamente como uma revista que publicava artigos de Sociologia Política, com uma pegada histórica forte, estudos de casos em profundidade. Passou por um período de transição em que os temas de teoria política passaram a ter um papel importante e cada vez mais estudos empíricos de orientação institucionalista têm ocupado um lugar significativo na produção da [Revista de] Sociologia e Política. (Perissinotto, 2015)

Por mais que a RSP tenha uma linha editorial definida e uma abordagem preferencialmente histórica e sociológica, ela não pode ficar impermeável à crescente predominância institucionalista na disciplina.

Não deixa de ser um paradoxo que o predomínio do viés institucionalista na área não tenha gerado condições institucionais satisfatórias para a produção da Ciência Política no Brasil, segundo alguns editores. Apesar de instituída a avaliação por pares, por exemplo, é pequeno o diálogo entre eles, conforme depoimento de Breno Bringel (2014) da Dados:

[...] um problema [...] é o como se produz o conhecimento da Ciência Política. [...] eu acho que o grande problema é que há pouco diálogo entre os pares, no sentido de como avançar em discussões substantivas. [...] Isso é muito difícil no Brasil, primeiro porque muitas das questões dos debates intelectuais são lidas, às vezes, como crítica pessoal, e isso é uma questão problemática, mas por outro, acho que existe pouca abertura institucional a essa polêmica intelectual e isso pode ser um papel das revistas científicas. (BRENO BRINGEL, Editor, Dados, 2014)

A questão de dificil resposta é saber se o estabelecimento de uma forte hierarquia na disciplina pode conviver com uma pluralidade de abordagens ou tende a promover a desigualdade entre as correntes teóricas e metodológicas.

O debate em tela transparece no tratamento do tema democracia. A democracia brasileira, ou sua forma de funcionamento, é considerada pela maioria dos editores como a "grande questão nacional" que tem sido analisada pelos cientistas políticos nos últimos dez anos.

A democracia que aparece na fala dos editores é marcada por tensões. Alguns enfatizam suas instituições políticas e pensam na democracia formal; outros valorizam a democracia substantiva e seus ideais de liberdade e igualdade. É evidente que a abordagem científica sobre a democracia não esteja separada da definição sobre a qual deve ser a sua experiência concreta. Essa necessidade de atenção da Ciência Política com a realidade da democracia brasileira, o compromisso com o presente e a especificidade da sociedade local expressam-se na fala de um dos editores da $R S P$, um veículo cujo viés é mais societal:

[...] exatamente nesse momento [o editor se refere à crise política associada, entre outras coisas, ao ciclo de manifestações de rua a partir de 2013] [...] 
você tem toda essa enxurrada de decepção [...] essa visão mais emocional e tal, então [...] e esse é um momento crucial, porque é um momento da gente parar e falar assim: [...] vamos entender, vamos pensar. Porque a gente não tá aqui tentando fazer a receita da Inglaterra, a receita dos EUA, ou a receita de qualquer outro país democrático, não dá, a gente tem que criar a nossa própria coisa, olhando para essas experiências, vendo o que a gente aprende com elas e olhando para nós. Por isso que a Ciência Política tem um papel muito importante nesse processo da qualificação da capacidade dos cidadãos brasileiros de entender a democracia. (PAULO COSTA, Editor, RSP, 2015).

As afirmações dos editores da Lua Nova e da RBCP oferecem mais indícios da tensão entre as abordagens institucionalista e societal da democracia. Segundo Cícero Araújo, a questão que orienta a maioria dos debates acadêmicos da Ciência Política é: "Qual o melhor arranjo para o sistema político brasileiro, a fim de consolidar a democracia no país?”. Luiz Felipe Miguel, por sua vez, chama atenção para o seguinte:"a Ciência Política brasileira, em grande medida, tem deixado de lado a questão central do impacto das desigualdades sociais no funcionamento da nossa democracia”. Essas posições expressam o perfil mais societal dos periódicos que editam.

O depoimento de Marta Arretche, uma das editoras da BPSR, periódico de abordagem neoinstitucionalista e politológica, por um lado surpreende por reconhecer a importância da perspectiva societal em Ciência Política, mas, por outro, confirma o diagnóstico de que talvez, mais que uma polarização, a disciplina viva uma tensão neste momento da sua trajetória:

[...] a Ciência Política avançou muito na compreensão da dimensão institucional, mas precisa avançar muito naquilo que se chama de Sociologia Política [...], o quanto os interesses societais e econômicos se inserem [...] afetam o funcionamento das instituições [...] toda a teoria institucional, ela diz assim: as instituições afetam o conflito entre os atores, $[\ldots]$ como os conflitos são resolvidos, mas os conflitos não são apenas entre atores institucionais [...] [eles] representam os interesses da sociedade, interesses econômicos, interesses privados. E sobre isso a gente sabe muito pouco. Eu acho que esse, talvez, seria o principal desafio. (MARTA ARRETCHE, Editora, BPSR, 2015)

Existem, portanto, sinais de reciprocidade, de reconhecimento da ala institucionalista sobre a importância da abordagem societal. $\mathrm{O}$ editor da $R S P$, que tem perfil mais heterogêneo e societal, reforça as palavras de Arretche ao reclamar da pouca atenção que a disciplina dá à história:

Um desses limites [da Ciência Política], a meu ver, é exatamente o que eu costumo chamar de presentismo na Ciência Política brasileira, é a falta absoluta de diálogo com a história. Então, você tem às vezes estudos com $\mathrm{N}$ gigantescos que são absolutas ficções estatísticas, [...] você tem testes de regressão maravilhosos etc.Você tem gente falando sobre cinco mil prefeitos no Brasil, como se todos os prefeitos fossem prefeitos igualmente em todas as cidades etc., [...] correndo-se o risco [...] das pessoas falarem mais sobre 
o banco de dados do que sobre a realidade propriamente dita. (RENATO PERISSINOTTO, Editor, RSP, 2015)

Cabe ressaltar que as afirmações sobre a aceitabilidade, relevância ou suficiência das instituições políticas democráticas, como objetos de análise da Ciência Política brasileira, vieram à tona de forma espontânea na fala dos editores quando foram convidados a fazer suas considerações sobre os limites, impasses e dilemas atuais da disciplina. Nesse contexto, o editor da Lua Nova questionou o significado restrito da palavra instituição:

Porque a gente não pode chamar de instituição qualquer tipo de prática social reiterada, mesmo que ela não seja oficial? [...] Especialmente quando você diz assim: instituições políticas são isso [...] e mais nada, você perde abertura [temática] e perde criatividade também, porque você vai analisando cada vez o menor, o pequeno dentro do objeto. (CÍCERO ARAÚJO, Editor, Lua Nova, 2015)

Convergem com esse posicionamento as afirmações dos editores de outros dois periódicos cujas propostas não são institucionalistas: a $R S P$ e da $R B C S$, respectivamente:

A hiperespecialização aumenta radicalmente o nível técnico da ciência, mas pode condená-la à irrelevância. A Ciência Política não é como a medicina: não faz muito sentido conhecer absolutamente tudo sobre o funcionamento do Legislativo, ou de algumas das suas comissões, conhecer todos os traços das elites parlamentares em duas legislaturas, conhecer tudo sobre o PT, ou conhecer tudo sobre a política de saúde no governo FHC e, ao mesmo tempo, perder de vista a integração da política ao sistema social mais amplo. (RENATO PERISSINOTTO, Editor, RSP, 2015)

A sociedade civil se institucionalizou, passou a assumir funções estatais, o Estado passou a fazer ativismo e essas duas coisas não estão separadas [...]. A literatura continua a olhar pra essas duas coisas como se se tratassem de fenômenos diferentes, e como se não fosse preciso produzir uma interpretação que permitisse entender quais são as dinâmicas e os mecanismos que levaram a produzir isso. [...] [mas esse] não é um tipo de problema que um institucionalista preocupado com partidos vai se colocar. (ADRIÁN GURZA LAVALLE, Editor, RBCS, 2015)

Lavalle retoma as preocupações manifestadas por Pogrebinschi (2010) e por Perissinotto (2004) sobre a necessidade de conciliar os olhares para apreender a dinâmica que envolve Estado e sociedade civil, ainda que no seu depoimento não expresse o mesmo otimismo deles.

Os dilemas a respeito da hegemonia institucionalista aparecem nas reflexões dos editores sobre a trajetória da Ciência Política. A maioria destaca a expansão da oferta de cursos de pós-graduação e o avanço metodológico alcançado pela disciplina, principalmente no uso de métodos quantitativos. Segundo Araújo, a trajetória da Ciência Política se faz "com o afastamento [...] da chamada Escola Sociológica Paulista [...] [e] passa a ter uma 
inclinação mais pra direção do institucionalismo [...] que acabou chegando ao Brasil e ganhando o mainstream da pesquisa acadêmica na Ciência Política". A preocupação com novos rumos para essa trajetória, no sentido de atenuar a hegemonia institucionalista, transparece na fala do editor da $R B C P$ ao responder que seria natural uma diversificação da agenda de pesquisa:

No período final da ditadura e começo da redemocratização a gente tem a transição democrática, como sendo o grande tema que mobiliza praticamente toda a Ciência Política. Com a democracia já mais estabelecida, mais consolidada, talvez, a gente tem uma diversificação é $[\ldots]$ um pouco maior. (LUIZ FELIPE MIGUEL, Editor, RBCP, 2015)

A realidade da democracia que direcionou a disciplina no seu início, pela análise da transição, poderia agora, a partir da sua consolidação, impulsionar a Ciência Política para uma nova fase, mais equilibrada entre os olhares institucionalistas e societais.

A respeito da necessidade de rever a agenda da Ciência Política brasileira, dando-lhe uma conotação mais interdisciplinar e plural, Araújo (2015) sentencia:

Eu acho que a nossa sociedade tem uma relação bastante ambígua, entre o visível e a sombra, o oficial e o não oficial [...] o que nos permitiria [...] até uma posição privilegiada pra estudar o fenômeno [...]. E acho que a Ciência Política deveria, até numa interação mais profunda com a Antropologia e a Sociologia, se preocupar e de certa maneira, estou remetendo aí a uma abertura da agenda [...] que é predominantemente institucionalista. Porque o institucionalismo tem a ver com o problema de definir a instituição pelo oficial, entendeu? E aí, ela acaba perdendo muito a sombra que eu estou falando [...] é um hábito social muito interessante de detectar e pesquisar. Alias faz parte da tradição do pensamento social brasileiro [...] que vale a pena resgatar.(CÍCERO ARAÚJO, Editor, Lua Nova, 2015)

Fica evidente o apelo para o equilíbrio nas abordagens e mudança na agenda da disciplina. O reconhecimento mútuo da importância das duas abordagens, societal e politológica, pode indicar uma nova tendência na disputa pela hegemonia no campo da Ciência Política.

\section{Considerações finais}

Ao final da análise da produção dos doutores em Ciência Política e da percepção dos editores dos periódicos, podemos avançar algumas considerações. A maior parte da produção publicada nos periódicos selecionados foi feita por autores cuja formação se concentra em cinco programas de pós-graduação: USP, UNICAMP, IUPERJ/IESP, UFMG e UFGRS. Os artigos desses atores evidenciam a prevalência do tema melhor avaliado na área: instituições políticas. A hierarquia de assuntos que marca o campo se mantém. O tema instituições políticas é mais presente do que democracia principalmente nos periódicos Dados e BPSR, confirmando a vocação institucionalista desses veículos 
também no caso específico da publicação dos doutores. Entretanto, chega a surpreender o fato de o periódico Opinião Pública, no caso dos doutores, apresentar grande proporção de artigos sobre instituições políticas. Por sua vez, Lua Nova e RBCS publicam mais textos dos doutores quando o tema é democracia, fenômeno que ocorre na RSP quando se trata de outros temas. Também é possível afirmar que a RBCP é uma exceção, pois ela tem baixa presença de artigos de doutores oriundos da USP e do IUPERJ/IESP.

O tratamento societal do tema democracia também é empreendido por uma minoria. Apenas nove artigos, dos 374 da amostra, articulam democracia com desigualdades. Neles, o enfoque é predominantemente normativo e a ênfase está na democracia substantiva em contraposição crítica à abordagem formal da democracia, proposta pelos institucionalistas. Também ficou manifesta a tensão entre as abordagens politológicas e societais e o apelo ao equilíbrio na agenda de pesquisa.

$\mathrm{Na}$ percepção dos editores transparece tanto a tensão pela hegemonia de temas na disciplina, com críticas ao predomínio institucionalista, quanto a defesa de uma agenda mais diversificada capaz de aproximar Estado e sociedade. O tema da democracia é central no mapeamento dos conflitos presentes no campo da Ciência Política brasileira.

\section{Referências}

AGUIAR, Neuma. Qual a contribuição dos Métodos Quantitativos em Ciências Sociais para o conhecimento da Sociedade Brasileira? In: ENCONTRO ANUAL DA ANPOCS, ST4, Caxambu-MG, 25., 2001. Anais .... Caxambu, 2001. Disponível em: https://www.anpocs.com/index.php/encontros/papers/25-encontro-anual-daanpocs/st-4/st04-3/4570-naguiar-qual-a/file. Acesso em: 2 ago. 2015.

AMORIM NETO, Octávio;SANTOS, Fabiano. La ciencia política en Brasil en la última década:La nacionalización y la lenta superación del parroquialismo. Revista de Ciência Política, Brasília, v. 35, n. 1, p. 19-31, 2015.

AVRITZER, Leonardo; GOMES, Lilian C. B. Política de reconhecimento, raça e democracia no Brasil. DADOS, Rio de Janeiro, v. 56, n. 1, 2013.

AZEVEDO, Fernando A. Mídia e democracia no Brasil: relações entre o sistema de mídia e o sistema político. Opinião Pública, São Paulo, v. 12, n. 1, 2016.

BALBACHEVSKY, Elizabeth; HOLZHACKER, Denilde O. O novo consenso da sociedade brasileira: democracia e igualdade. Opinião Pública, São Paulo, 2012.

BARBOZA, Danilo; GODOY, Samuel. Superando o 'calcanhar metodológico'? Mapeamento e evolução recente da formação em métodos de pesquisa na pós-graduação em Ciência Política no Brasil. In: SEMINÁRIO DISCENTE DA PÓS-GRADUAÇÃO EM CIÊNCIA POLÍTICA DA USP, 4., 2014, São Paulo. Anais ... São Paulo, 2014.

CANO, Ignácio. Nas trincheiras do método. Sociologias, Porto Alegre, n. 31, ano 14, 2012.

CERVI, Emerson U. O papel da ciência política no discurso científico brasileiro. BIB, São Paulo, n. 82/2, 2018.

CGEE - CENTRO DE GESTÃO DE ESTUDOS ESTRATÉGICOS. Mestres e Doutores 2015: Estudos da demografia da base técnico-científica brasileira. Brasília, 2016. Disponível em: https://www.cgee.org.br/ documents/10195/734063/Apres_CGEE_MD2015_SBPCvfrev.pdf Acesso em: 5 fev. 2018.

COUTINHO. Marcelo. Democracias Andinas: chegando tarde à festa? DADOS, Rio de Janeiro, v.49, n.4, 2006.

GURZA LAVALLE, Adrian;VERA, Ernesto I. A trama da crítica democrática: da participação à representação e à accountability. Lua Nova, São Paulo, n. 84, p. 95-139, 2011. 
LAMOUNIER, Bolívar. A Ciência Política no Brasil: Roteiro para um Balanço Crítico. In: LAMOUNIER, Bolívar (Org.). A Ciência Política nos anos 80. Brasília: Universidade de Brasília, 1982.

LEITE, Fernando. O campo da produção da Ciência Política brasileira contemporânea: Uma análise histórico-estrutural de seus princípios de divisão a partir de periódicos, áreas e abordagens. 2015. Tese (Doutorado em Sociologia) - Universidade Federal do Paraná, Curitiba, 2015.

LEITE, Fernando; CODATO,Adriano. Autonomização e institucionalização da Ciência Política brasileira: o papel do sistema Qualis-Capes. Revista de Discentes de Ciência Política da UFSCAR, São Paulo, v. 1, n. 1, p. 1-21, 2013.

LIMONGI, Fernando;ALMEIDA, Maria H.; FREITAS, Andréa. Da Sociologia Política ao (neo) institucionalismo: trinta anos que mudaram a ciência política no Brasil, Academia Edu, 2015. Disponível em: https://www. academia.edu/15209689/DA_SOCIOLOGIA_POL\%C3\%8dtica_ao_neo_institucionalismo_trinta_anos_que_ mudaram_a_ci\%C3\%8ANCIA_POL\%C3\%8DTICA_NO_BRASIL.Acesso em: 09 set. 2015.

LOPES, Dawisson E. B. Relações econômicas internacionais, isomorfismo institucional e democracia na América Latina: explicando as convergências (inesperadas?) entre Uruguai, Brasil e Honduras. DADOS, Rio de Janeiro, v. 50, n. 3, p. 611-652, 2007.

LYNHC. Christian E. A primeira encruzilhada da democracia brasileira: os casos de Rui Barbosa e de Joaquim Nabuco. Revista de Sociologia e Política, Paraná, v. 16, número suplementar, 2008.

MARENCO, André. The Three Achilles' Heels of Brazilian Political Science. Brazilian Political Science Review, Brasil, v. 8, n. 3, p. 3-38, 2014.

MARQUES, Danusa. Democracia e Ciências Sociais no Brasil, 1985-2005. 2007. Dissertação (Mestrado em Ciência Política) - Universidade de Brasília, Brasília, 2007.

MARQUES, Danusa; MACHADO, Carlos A. M. Democracia e Desigualdade nas Ciências Sociais Brasileiras Artigos Publicados entre 2000 e 2010. In: IX ENCONTRO DA ASSOCIAÇÃO BRASILEIRA DE CIÊNCIA POLÍTICA, Brasília, 4 a 7 ago, 2014. Disponível em: https://cienciapolitica.org.br/system/files/documentos/ eventos/2017/04/democracia-e-desigualdade-nas-ciencias-sociais-brasileiras.pdf . Acesso em: 05 ago. 2015.

MOISÉS, José A. Os brasileiros e a democracia: as bases sociopolíticas de legitimidade democrática. São Paulo:Ática, 1995.

MOISÉS, José A. Os significados da democracia segundo os brasileiros. Opinião Pública, São Paulo, v. 16, n. 2, 2010.

MOREIRA, Marcelo S. A poliarquia brasileira e a reforma política: análise de uma contribuição de Wanderley Guilherme dos Santos à Teoria Política. DADOS, Rio de Janeiro, v.57, n.2, p. 293-323, 2014.

MUSSI, Daniela. Uma ciência política para um Brasil democrático, 2014. Disponível em: http://danielamussi.com. br/wp-ontent/uploads/2016/02/MUSSI_Daniela._Uma_ciencia_politica_para.pdf . Acesso em: 22 set. 2015.

NEIVA, Pedro. Revisitando o calcanhar de Aquiles das Ciências Sociais no Brasil. Sociologia, Problemas e Práticas, Portugal, n. 79, s/v, p. 65-83, 2015.

OlIVEIRA, Lilian; NICOLAU, Jairo. A Produção da Ciência Política Brasileira: Uma Análise dos Artigos Acadêmicos (1966-2013). In: ENCONTRO DA ASSOCIAÇÃO BRASILEIRA DE CIÊNCIA POLÍTICA, 9., 2014, Brasília. Disponível em: https://cienciapolitica.org.br/system/files/documentos/eventos/2017/03/ producao-ciencia-politica-brasileira-analise-dos-artigos.pdf. Acesso em: 27 mar. 2015.

PERISSINOTTO, Renato M. Política e sociedade: por uma volta à sociologia política. Política E Sociedade, Santa Catarina, s/v, n. 5, p. 203-232, 2004.

POGREBINSCHI, Thamy. Democracia Pragmática: Pressupostos de uma Teoria Normativa Empiricamente Orientada. DADOS, Rio de Janeiro, v.53, n.3, p. 657-693, 2010.

REIS, Fábio W. Huis clos no Chile e ciência política no Brasil. Research Gate, 2015. Disponível em: https://www. researchgate.net/publication/311510924_Huis_clos_no_Chile_e_ciencia_politica_no_Brasil Acesso em:30 out. 2015.

REIS, Fábio W. Avaliação das Ciências Sociais. PT.SCRIBD, 1993. Disponível em: http://pt.scribd.com/ doc/59740251/Avaliacao-das-ciencias-sociais\#scribd. Acesso em: 03 fev. 2015. 
REIS, Fábio W. O Tabelião e a Lupa: teoria, método generalizante e idiografia no contexto brasileiro. Revista Brasileira de Ciências Sociais, São Paulo, v. 6, n. 16, 1991.

REIS, Elisa P.; REIS, Fábio W.; VELHO, Gilberto. As Ciências Sociais nos 20 anos: Três Perspectivas. Revista Brasileira de Ciências Sociais, São Paulo, v. 12, n. 35, 1997.

SOARES, Gláucio. O Calcanhar Metodológico da Ciência Política no Brasil. Sociologia, Problemas e Práticas, Portugal, s/v, n. 48, p. 27-52, 2005.

SOUZA, Cláudia D. de; FILIPPO, Daniela de; CASADO, Elías S. Crescimento da atividade científica nas universidades federais brasileiras: análise por áreas temáticas. Avaliação, São Paulo, v. 23, n. 1, p. 126-156, mar., 2018. Disponível em: http://www.scielo.br/pdf/aval/v23n1/1982-5765-aval-23-01-00126.pdf Acesso em: 25 jun. 2018.

VITULLO, Gabriel. As teorias da democratização frente às democracias latino-americanas realmente existentes. Opinião Pública, São Paulo, v. 12, n. 2, p. 348-377, 2006.

\title{
Tension in Brazilian Political Science: the production of doctors and the perception of editors
}

\begin{abstract}
Political Science in Brazil experiences tensions between institutionalist and societal approaches. For some the predominant role of institutionalism is positive. Others believe that this hegemony creates inequality in the area and undermines the reflection on democracy. Our objective is to describe the recent production (2005-2014) in important journals in the field of Political Science comparing institutionalism and societalism and giving special attention to the articles on democracy and inequality. We observe, quantitatively and qualitatively, the production of doctors in political science in seven major scientific journals. The perception of the journal editors about this process completes the corpus. We conclude that the institutionalist hegemony is confirmed in the production of doctors, but not without generating dissatisfaction.
\end{abstract}

Keywords: Political Science. Doctors. Publishers. Journals. Articles.

\section{Tensión en la Ciencia Política brasileña: la producción de los doctores y la percepción de los editores}

\section{Resumen}

La Ciencia Política en Brasil experimenta tensiones entre los enfoques institucionalista y societal. Para algunos es positivo el papel preponderante del institucionalismo. Otros entienden que esta hegemonía crea desigualdad en el área y perjudica la reflexión sobre la democracia. Nuestro objetivo es describir la producción reciente (2005-2014) en importantes revistas del campo de la Ciencia Política comparando institucionalismo y societalismo y prestando especial atención a los artículos sobre democracia y desigualdad. Observamos, cuantitativamente y cualitativamente, la producción de los doctores en Ciencia Política en siete importantes periódicos científicos. La percepción de los editores de los periódicos sobre ese proceso completa el corpus. Concluimos que la hegemonía institucionalista se confirma en la producción de los doctores, pero no sin generar insatisfacciones.

Palabras clave: Ciencia Política. Doctores. Editores. Revistas. Artículos.

Data de recebimento do artigo: 15/08/2018

Data de aprovação do artigo: 09/05/2019 